\title{
GLOBAL AQUACULTURE GROWTH AND INSTITUTIONAL QUALITY
}

Suthamathy Nadarajah and Ola flaaten

Norwegian College of Fishery Science, UiT-The Arctic University of Norway, N-9037 Troms $\varnothing$, Norway.

Email: suthamathy.nadarajah@uit.no and ola.flaaten@uit.no

\section{ABSTRACT}

The global aquaculture sector has grown continuously over the past 40 years, though unevenly among countries. Differences in factors such as inputs, climate, management, technology, markets, social environment, and institutions might be reasons for the disparities in growth. This study focuses on institutions, by analyzing the relationship between annual growth in the production of the major aquaculture countries and the quality of their institutions over three decades (1984-2013). Based on an ex-ante set of criteria, seventy-four aquaculture countries from five different regions - Africa, the Americas, Asia, Europe and Oceania - were selected. Annual percentage change in total aquaculture production, in terms of quantity and value, was used as a proxy for sector development. Three indices - governance, corruption, and competitiveness - were used as institutional quality proxies. Empirical results suggest that the aquaculture growth did not significantly correlate with the quality of institutions. By region, Africa had the fastest growth in the aquaculture sector, though from a low base, with $7.35 \%$ and $9.28 \%$ higher annual percentage change in aquaculture quantity and value respectively, than the Asian region. While, the European region experienced significantly lower annual percentage change in aquaculture quantity, a difference of $3.78 \%$ compared to the Asian region. Furthermore, the study found that total aquaculture production was not positively correlated with eco-label certification. The study is concluded by discussing the "aquaculture paradox."

Keywords: aquaculture, growth rates, good governance, resource curse, sustainable development 


\section{INTRODUCTION}

Over the past 40 years, the global aquaculture sector has grown continuously and the sector is currently an important contributor to total global seafood production; according to the Food and Agriculture Organization (FAO) of the United Nations, it contributed 44.1 percent in 2014 [1]. Global supply from aquaculture has grown at an annual average of 8.6 percent between 1980 and 2012 [2], whereas the capture fish production gradually stagnated. The average annual percentage change in global aquaculture production in terms of value is 3.9 percent in the period 1984-2014. This development has mainly been driven by productivity growth [3, 4] and an increasing demand for seafood [5]. Global food fish production through aquaculture was 73.8 million tons in 2014, and total global aquaculture production, including farmed aquatic plants, was 101.1 million tons, valued at US\$ 165.8 billion [1]. Asia dominates this production, accounting for 88.91 percent by volume in 2014 .

The dietary contribution of seafood is important in terms of animal protein and micro nutrients. Statistics on world per capita fish consumption show that the consumption has increased gradually. In 2013, world per capita fish consumption was $19.7 \mathrm{~kg}$ [1]. The continuous growth in aquaculture production has boosted the average consumption of seafood at the global level. The global aquaculture sector's contribution to the supply of seafood for human consumption surpassed that of capture fisheries in 2014 [1]. Aquaculture is now more important than fisheries as a source for seafood for human consumption. Fish consumption is estimated to increase further in countries in Asia, Africa, America, and European regions during 2010 2030 [6]. Given the contribution by the global aquaculture sector to food security, the sustainable development of the aquaculture sector is an important requirement to meet future demand from a world population of 9.6 billion by 2050 .

Despite the production increase, the overall rate of growth in the aquaculture sector is decreasing on a global scale (see Figure 1). Furthermore, disparities in aquaculture growth 
among aquaculture countries has been observed for many years. Generally, aquaculture production depends on several factors, and the interactions between them, including fingerlings, feed, farming area, climatic factors, farming systems, management practices, market factors, social environment, and institutions. An increase in factor inputs increases aquaculture outputs. However, feed waste, feces, escapement and pathogens may cause negative externalities among producers and between the aquaculture industry and other parts of the economy. Differences in input factors in aquaculture production might be reasons for the growth disparities. Marine resource abundance, farming practices, technology, and markets have been discussed as critical factors that contributed to the growth experienced in recent decades [7-9].

[Figure 1 to be inserted about here.]

This study focuses on institutions and investigates empirically whether the quality of national institutions has influenced aquaculture growth and development. The role of the qualitative factor institutions, in aquaculture production could also be a determinant, in particular in the long run. Institutions are key components in the overall management of natural resource industries, guiding the people involved in their task of production and marketing. Institutions include governmental policy, laws, rules and regulatory measures, planning, programs (training, extension services, and financial assistance) and controls. Institutions may change over time to create improved environment for technological change and economic development [10].

\section{BACKGROUND}

"Why do some countries produce so much more output per worker than others?" was the key question posed by Hall and Jones [11], as well as in the voluminous literature in the field of growth and development economics. This cross-country study of 127 entities found that 
designated social infrastructure (institutions and government policies) is of great importance for economic development and productivity. A good social infrastructure creates a favorable environment that supports production, encourages capital accumulation, skill acquisition, invention, and technology transfer. There is a "powerful and close association between output per worker and measures of social infrastructure" [11], considering input and output data.

The role of institutions in the performance of resource economies has been discussed in the "resource curse literature" [12-14]. The resource curse - that natural resource abundance is harmful to economic growth- is a finding from an earlier study on the economic development history of resource economies conducted by Sachs and Warner [15]. They concluded that resource abundance is not a blessing, but rather it hampers economic growth. The main causes of this, identified based on theory and the study of many countries, include rent-seeking behavior, civil war, armed conflict, political instability, and the decay of institutional quality. Empirical studies have identified a negative correlation between resource abundance and economic growth $[14,15]$.

However, researchers who later studied the same research questions partly argued the findings of earlier studies and partly introduced new elements to explain the anomalies found ${ }^{1}$. They have suggested that a hidden factor determines whether natural resource abundance is a blessing or a curse, namely the quality of institutions $[12,13]$. These studies demonstrate, both theoretically and empirically, that a country could attain economic growth through its abundant natural resources if it maintains high-quality institutions. Weak institutions provide opportunities for rent seekers to keep some production outside the formal economy and to employ resources for unproductive rent seeking, causing negative impacts for the overall

\footnotetext{
${ }^{1}$ These research questions ask why growth rates differ among resource-rich countries even though they depend on similar natural resources, and why the growth rates of many resource-rich economies are lower than those of economies less abundant in valuable natural resources.
} 
economy and low economic growth [12]. However, institutions alone do not determine the outcomes of resource use. The type of resource also influences economic results [13]. The natural resources considered in the literature as contributors to economic growth are mainly valuable mineral resources, including crude oil, gas and diamonds, all of which are highly traded internationally.

Marine renewable resources are also valuable natural resources. The fishery and aquaculture sectors play a significant role in achieving socioeconomic development. Seafood products are highly traded internationally, about 78 percent of seafood products estimated to be exposed to international trade competition [16-18]. In 2014, more than 200 countries reported exports and imports of seafood products [1]. Since the quality of institutions is proved to be a crucial factor contributing to economic growth through non-renewable resource-based industries, what would be the effect of institutions on the performance of limited renewable resource-based industries? This question was recently studied for the fishery sector, but in a different manner than that of previous studies on nonrenewable resources, as fisheries in most countries play a minor role in the national economy [19]. A major finding of this empirical study was that national institutions do not play a significant role in the harvest growth rate, and this statistical finding contrasts with the previous finding in the resource curse literature that institutions have a significant influence on the contribution of resource industries to the growth of the gross domestic product (GDP). In this context the fisheries sector is a special case compared to other natural resource-based industries.

Although both fisheries and aquaculture are similar industries in producing food fish, the aquaculture sector differs from the fishery sector in some important ways [9]. The aquaculture sector is a man-made ecosystem, generating both positive and negative consequences for the surrounding natural ecosystems [20]. Aquaculture is in some respects more similar to agriculture than to fisheries, in particular since the stock of animals is private property [9]. On 
the other hand, aquaculture fish are to a high degree exposed to and create externalities, as noted above [20]. This is particularly the case for cage-reared fish, such as salmon in Chile and Norway [21], but also for pond-raised species, such as shrimp in Sri Lanka and Vietnam. This distinct industry requires special management measures to overcome the externalities. As a component of the management system, institutions might influence aquaculture production in different ways. Therefore, this study aims to examine the extent to which national institutions influence aquaculture production and value (see Figure 2).

[Figure 2 to be inserted about here.]

Comparative analyses of the determinants of the general economic performance of countries traditionally use macroeconomic indicators such as GDP per capita (level and change) as the dependent variable $[11,12,15]$. On the other hand, there are numerous sectorial studies where the sector output (net or gross, level or change) is the dependent variable. This literature includes studies of the primary industries agriculture [22,23] and fisheries [19]. The quoted agriculture studies focused on output levels whereas the quoted fishery study focused on annual change. The main reasons for this difference appears to be the availability or lack of crosssectional data as well as time series data. For aquaculture, input data, to the best of our knowledge, is not available the same way internationally, and we have rather to perform a study of output growth for quantity and value. The relationship between the annual growth rate in aquaculture production of the major aquaculture countries and the quality of institutions in those countries over the last three decades (1984-2013) is analyzed using econometric models.

\section{METHODS AND DATA}

The main hypothesis is that growth and development of the aquaculture sector depend on the quality of national institutions, i.e. that high-quality institutions have a positive effect on aquaculture production. The research questions to be discussed are: How and to what extent is 
aquaculture performance influenced by national institutions, through correlation? Do the countries performing well in the aquaculture sector have effective national institutions? Is the aquaculture sector a special case compared to other natural resource-based industries, requiring special institutional arrangements for sustainability? Do the countries performing well in the aquaculture sector use any standard procedures (e.g. eco-label certification)?

\subsection{Aquaculture Countries and Production Data}

The study includes many aquaculture countries in order to provide a global picture. Generally, the FAO considers the top 30 countries when listing the largest aquaculture producers in the world. This study considers double that number, analyzing the top 60 countries. The countries were selected using the criteria that a country should belong to at least one of the following categories:

- One of the 60 largest aquaculture countries in terms of quantity (in tons) for the years 1984-1985, 1994-1995, 2004-2005, or 2012-2013.

- One of the 60 largest aquaculture countries in terms of value (in US\$) for the years 1984-1985, 1994-1995, 2004-2005, or 2012-2013.

Initially 79 countries were selected based on the above criteria, including the former nations the Soviet Union and Yugoslavia. Three countries-Belize, the Faroe Islands and French Polynesia-were omitted from the econometric analysis, as scores for the good governance indicators chosen in this study are not available for these countries. Finally, 74 countries were included in the main econometric analysis.

The study used the latest data published by the FAO [24] for aquaculture production in its Fisheries and Aquaculture Statistics (FishStat) database. FishStat contains data for aquaculture production from 1950 to 2013. Data for the quantity of aquaculture production are available from 1950, but data for the value of aquaculture production are only available from 1984. Thus, 
the study covers the period 1984-2013, even though the global aquaculture sector has a long history of over 50 years. Total aquaculture production including all species (finfish, crustaceans, molluscs and aquatic plants) was taken into account. Data for total aquaculture production in terms of quantity (in tons) and value (in US\$) from 1984 to 2013 were collected from the FAO database using the FishStatJ software. The present day countries Belarus, the Russian Federation and Ukraine belonged to the Soviet Union, and Croatia belonged to Yugoslavia. Therefore, it was necessary to estimate the figures for aquaculture production in these countries during the period in which they were united. The approximate figures for the quantity and value of aquaculture production were estimated using the data for the former nations (Soviet Union and Yugoslavia) in the FAO database ${ }^{2}$. The selected countries were grouped into five different regions-Africa, the Americas, Asia, Europe, and Oceania-by following the FAO classification.

The annual percentage change and the average annual percentage change in aquaculture production (quantity and value) in the period 1984-2013 were calculated for each country. The terminal years, 1985 and 2013, used to calculate the average annual percentage change, are the average of two adjacent years (1984-1985 and 2012-2013); this average annual percentage change is the compounded annual change in production.

\subsection{Good Governance Indicators}

\footnotetext{
${ }^{2}$ The approximate figures for Belarus, the Russian Federation and Ukraine from 1984 to 1987 and for Croatia from 1984 to 1991 were calculated in the following way, using the example of Belarus:

Aquaculture production for the Soviet Union in 1984 was multiplied by the proportion of Belarussian production of the average of the former Soviet countries' total aquaculture production in the period 1988-1989. This proportion was assumed to be constant and multiplied by the aquaculture production of the Soviet Union in the respective years.

The former Soviet countries included: Armenia, Azerbaijan, Belarus, Estonia, Georgia, Kazakhstan, Kyrgyzstan, Latvia, Lithuania, Tajikistan, Moldova, the Russian Federation, Turkmenistan, and Ukraine.

The former SFR Yugoslavia countries included: Croatia, Bosnia, Herzegovina, Montenegro, Macedonia, Serbia, and Slovenia.
} 
Institutions comprise a qualitative feature that can be assessed using indices. For the last two decades, the quality of national institutions has been assessed using good governance indictors produced by international organizations. It is not possible to select a single indicator as a measure that can completely explain the quality of national institutions. National institutions include the whole government policy framework of a country to guide and influence all economic activities, including the aquaculture sector. Even though the aquaculture industry is a food-producing sector, it is a highly competitive, business-oriented sector in the world. Therefore, three indices were selected: the World Bank's Worldwide Governance Indicators (WGI), Transparency International's Corruption Perceptions Index (CPI) and the World Economic Forum's Global Competitiveness Index (GCI) (see Figure 2). In addition to these three indices, another three aspects were included in the econometric analysis: Membership of the Organization for Economic Cooperation and Development (OECD), use of an eco-label certification program and region.

\subsubsection{Worldwide Governance Indicators (WGI)}

The WGI reports [25] the quality of governance on six dimensions for 215 countries over the period 1996-2014. The World Bank and the Brookings Institution developed the WGI score on a scale ranging from -2.5 (bad) to 2.5 (good), using over 32 different data sources, including commercial information providers, surveys of firms and households, nongovernmental organizations, and public sector organizations. As the World Bank defines it:

Governance consists of the traditions and institutions by which authority in a country is exercised. This includes the process by which governments are selected, monitored and replaced; the capacity of the government to effectively formulate and implement sound policies; and the respect of citizens and the state for the institutions that govern economic and social interactions among them. 
By definition, the ability of the government to produce and implement policies and deliver public goods and services is referred to as government effectiveness. Aquaculture production depends on the availability and accessibility of aquaculture inputs and facilities: fingerlings, medicine, feed, electricity, water supply, transport facility and market facilities. Generally, provision of these inputs and facilities is determined by government progress. So that, within the six dimensions of governance, two indicators (government effectiveness and regulatory quality) were chosen to calculate the WGI score used in this study. The average score of these indicators was used as the country's WGI score. The WGI scores for the selected aquaculture countries were collected from World Bank reports (1996-2013). Over the period 1996-2002, the World Bank published the WGI scores every two years, so the score for a given year was assumed to be valid also for the adjacent year.

\subsubsection{Corruption Perceptions Index (CPI)}

Control of corruption is one of the six dimensions of governance in the WGI. However, there is also another specialized index available to explain the level of corruption, named the "Corruption Perceptions Index (CPI)", by Transparency International. Data for this index is available from 1995 annually. Therefore CPI was selected, which enable more data.

The CPI measures the perceived level of public sector corruption in countries worldwide, providing a ranking. The CPI scores range from zero (highly corrupt) to ten (very clean). Scores for the selected countries were collected from annual reports for the period 1995-2013 [26].

Environmental degradation is a consequence of a corrupt system. Highly corrupt situations provide opportunity for individuals to act freely: usage of natural water reservoirs, destruction of mangrove forests, usage of banned medicine and illegal farming. So this index could explain how a country practices good governance measures to reduce the environmental degradation caused by aquaculture. 


\subsubsection{Global Competitiveness Index (GCI)}

The GCI is a comprehensive index for measuring national competitiveness. Competitiveness is defined as the set of institutions, policies, and factors that determine the level of productivity of a country [27]. The index is used to evaluate the capability of a country to achieve economic growth and provide information regarding productivity and competitiveness. Since 2005, the World Economic Forum has annually ranked countries, providing a score on a scale from one to seven. The determinants of economic growth are grouped into 12 "pillars", including institutions, for the calculation; the weighted average of the many different components is the final score. The GCI scores for the chosen countries were collected from the reports for the period 2004-2013 [28].

\subsubsection{Eco-label Index}

Eco-labelling is a form of certification program, aiming to avoid the negative environmental and socioeconomic effects caused by aquaculture (pollution, disease incidence, social conflict) and improve its sustainability. Recently, most aquaculture countries have adopted certification to ensure that their farming activities are undertaken in an environmentally friendly manner. Some of the countries included in this study practice ecolabel certification and others do not. Thus, to study the effect of eco-label certification on aquaculture production, eco-labeling was included in the econometric model as a dummy variable. Best Aquaculture Practices (BAP) and Aquaculture Stewardship Council (ASC) certification were chosen to represent eco-label certification; each is described in turn below:

- BAP certification was established in 2002 to promote responsible practices across the aquaculture industry. The BAP standards were developed by the Global Aquaculture Alliance, focusing on biodiversity conversion and environmental, social, food safety, and traceability issues. The certification program is implemented through the Aquaculture Certification Council, an agency that provides certification licenses to the 
entire aquaculture production chain, including farms, hatcheries, and seafood processing plants. The agency inspect all practices and product quality, and reviews records.

- The Aquaculture Stewardship Council (ASC) was founded in 2010 by the World Wide Fund for Nature (WWF) and the Dutch Sustainable Trade Initiative (IDH). It aims to transform aquaculture toward environmental sustainability and social responsibility, using efficient market mechanisms that create value across the chain. The ASC provides standards for the farmed seafood chain of custody. The standards for certification have been developed and are implemented in accordance with the International Social and Environmental Accreditation and Labeling Alliance (ISEAL) guidelines.

\subsubsection{Organization for Economic Cooperation and Development (OECD)}

The OECD is an international economic organization established in 1960. Its mission is to promote policies that will improve the economic and social well-being of people around the world. Originally, the United States, Canada, and 18 European countries signed; since then, another 14 countries have become members of the organization. Recently some countries have joined as partners in the OECD. Most members are economically developed countries and employ good strategies to manage their natural resources. Our study includes 28 OECD member countries, with membership included as a dummy variable to investigate how OECD countries perform in aquaculture compared to non-OECD countries.

\subsubsection{Region}

Aquaculture was more popular in developed countries in the early years, but globalization has seen the aquaculture sector expand more rapidly in developing nations. To test the regional effect, we ran regressions replacing OECD with regional dummy variables. We follow regional categories according to the FAO grouping, denoting Africa, the Americas, Asia, Europe, and 
Oceania as R1, R2, R3, R4, and R5 respectively. The global aquaculture sector is currently dominated by the Asian region with around $88.9 \%$ of global aquaculture production coming from Asian countries [1]. Thus, the Asian region (R3) was chosen as the benchmark to study the regional effect.

\subsection{Model}

As discussed above, most studies in the resource curse literature have used GDP growth as the dependent variable to study the role of institutions in the economic performance of resourcerich economies. However, this paper uses another approach, taking the annual growth rate of the industry output as the dependent variable. This is a similar approach to that used for fisheries [19] and agriculture [23]. Differences and similarities among aquaculture, fishery and agriculture vary between countries. This may explain why the aquaculture sector administratively is a subsector of the fishing industry in most countries while it is a subsector of agriculture in some other countries, such as China. The contribution of the aquaculture sector to the GDP is not reported separately, but is combined with marine fishery or agriculture in national statistical reports. Due to the lack of available GDP and profitability data, annual percentage change in total aquaculture production in terms of quantity and value was used as proxy for sector development. The basic econometric model given in Equations (1) and (2) illustrate the relationship between the annual growth rate and the institutions:

$$
\begin{aligned}
& i=\beta_{1}+\beta_{2} \mathrm{WGI}+\beta_{3} \mathrm{CPI}+\beta_{4} \mathrm{GCI}+\beta_{5} \mathrm{OECD}+\beta_{6} \mathrm{BAP} \_\mathrm{ASC}+\beta_{7} \mathrm{R} 1+\beta_{8} \mathrm{R} 2+\beta_{9} \mathrm{R} 4+\beta_{10} \mathrm{R} 5 \\
& +\mathrm{e}
\end{aligned}
$$

Equation (1) is a multiple linear regression and will be estimated using the ordinary least square method (OLS). It explains the relationship between the average annual percentage change in production and national institutions. 
$i=\beta_{1}+\beta_{2} \mathrm{WGI}+\beta_{3} \mathrm{CPI}_{j t}+\beta_{4} \mathrm{GCI}_{j t}+\beta_{5} \mathrm{OECD}_{j t}+\beta_{6} \mathrm{R}_{j t}+\beta_{7} \mathrm{R} 2_{j t}+\beta_{8} \mathrm{R}_{j t}+\beta_{9} \mathrm{R}_{j t}+\mathrm{e}_{j t}$

Equation (2) is a panel regression and will be estimated using the pooled least square method. It explains the relationship between the annual percentage change in production and national institutions.

$i$ is the annual percentage change in production, WGI, CPI, and GCI are the indices representing the quality of institutions, $\mathrm{OECD}$ is a dummy variable for membership, BAP_ASC represents BAP and/or ASC eco-labeling certification, $\mathrm{R}$ is a regional category and e is the error term. The subscript $j$ denotes the $j$ th individual (74 countries) and $t$ denotes time (29 years).

The entire set of data used in this study is an unbalanced panel data set. The main limiting factor is the lack of score for indices over the full period, as discussed above. The econometric analysis was done in two different ways using the R statistical software (version 3.1.1), as set out below.

1) Cross-country regression (Equation 1): The average annual percentage change in production in the period 1984-2013, as the dependent variable, was regressed against all good governance indices, as well as the dummy variables, using the ordinary least squares (OLS) method. The average score for each index in the last two years (2012 and 2013) was used in this regression. The data set used for this regression is given in the appendix, Table A1.

2) Panel data regression (Equation 2): The panel data include 74 countries, data for production over the 29-year period, and scores for the indices (WGI, CPI, and GCI) for 20 years. The annual percentage change in production, as the dependent variable, was regressed against the scores for the three good governance indices in the respective year and the OECD and region dummies. Lack of time series information regarding eco-labeling is the reason for omitting the ecolabel index. Initially, all three panel data regression models-pooled, fixed effects and 
random effects-were estimated and tested using formal methods [29]. Random effects models for quantity data and pooled models for value data were selected based on the test results; Breusch-Pagan Lagrange Multiplier test, Hausman test and Breusch-Godfrey/Wooldridge test [30,31]. The fixed effects model is unable to estimate the coefficient on the time-invariant such as the OECD and region dummy variables, therefore the random effects model is suited and there is no endogeneity problem in these models. Regressions 5 and 7 are random effects models and regressions 6 and 8 are pooled models (Table 1). To test the regional effect, regressions 7 and 8 were estimated by replacing OECD with regional dummy variables; the Asian region (R3) was considered as the benchmark.

\section{RESULTS}

Appendix Table A1 reports the average annual percentage change in production (quantity and value) over the period 1985-2013 for the 74 aquaculture countries and the scores on the indices (WGI, CPI, GCI) for those countries (average of the two latest years, 2012 and 2013). The scores for WGI, CPI and GCI show that the quality of institutions varies among the selected aquaculture countries. The list for the top ten aquaculture producers include countries with poor-quality institutions (China, India, Indonesia, Vietnam, Bangladesh Thailand and Philippines) as well as with high-quality institutions (Chile, Norway, and Japan). There are small aquaculture producers having high quality institutions (Sweden, Finland, and Iceland). Thus, globally, it is a mixed picture.

Appendix Table A2 summarizes the correlation between the main variables. The average annual change in production has a weak, negative correlation with all explanatory variables. Columns (1) - (4) in appendix Table A3 show the cross-country regression results for Equation (1). Most of the signs of the coefficients of good governance indicators (WGI, CPI, and GCI) are negative, but the $t$-values indicate that the coefficients are not significantly different from zero, indicating that institutions do not have a significant influence on aquaculture production. 
For BAP_ASC, the coefficient is negative, but not statistically significant, which suggests that eco-label certification doesn't have a measurable effect on aquaculture production. These cross-country regression results (Regression 1-4) might not be precise. As can be seen, the correlation matrix (Appendix Table A2) indicates that the good governance indicators chosen in this study are highly correlated, resulting in multicollinearity problems. Furthermore, the tests undertaken to verify models indicates that this model has problems and may be misspecified.

Panel-data regression could be the best way to overcome the problems encountered in the crosscountry regression. The panel data regression results are given in columns (1) - (4) in Table 1. Regressions 5 and 7 are random effects models and regressions 6 and 8 are pooled models (Equation 2). The results indicate that the annual growth rates in aquaculture production are not significantly influenced by the quality of institutions (WGI and CPI). Even though the sign of the coefficient for GCI is negative, it is statistically significant at the $10 \%$ level (regression 5), showing that when the competitiveness of countries increases (including policies, rules, regulatory measures), the quantity of aquaculture production decreases.

[Table 1 to be inserted about here.]

The sign of the coefficient for OECD membership is negative, but the coefficient is not statistically different from zero (Table 1, regressions 5 and 6). These results indicate that both OECD countries and non-membership countries experienced similar development in the aquaculture sector over the period 1985-2013. However, the model (Equation 3) estimated using the top 30 aquaculture producers' production value and institutional quality shows that 
OECD member countries have had 5.30\% lower annual growth in aquaculture value compared to non-OECD countries ${ }^{3}$.

The results for regressions 7 and 8 (Table 1) indicate that in terms of region, Africa had the fastest growth in the aquaculture sector, though from a low base, with a $7.35 \%$ higher annual percentage change in aquaculture quantity as well as a $9.28 \%$ higher annual percentage change in aquaculture value than the Asian region. The European region experienced significantly lower annual percentage growth in aquaculture quantity, a difference of $3.78 \%$ compared to the Asian region.

The scores for the good governance indicators selected in this study show that the quality of institutions in many Asian countries is poor. It could be that weak institutions provide opportunities to overexploit marine resources and create an unstable market situation. To check this claim, we ran regressions for 26 countries' aquaculture production and national institutional quality. The regression result (Equation 4) indicates the sign of the coefficient for CPI is negative and significant at the $10 \%$ level ( $t$-value in parenthesis) revealing that the annual growth rate (value) is negatively affected by the corruption level in the Asian region.

$i^{\text {val }}=33.107(2.207)+2.323(0.638) \mathrm{WGI}+0.438(0.340) \mathrm{CPI}-5.544(-1.612) \mathrm{GCI}-5.3$

$(-1.743)$ OECD

$i^{\text {val }}=30.079(1.430)+5.951(1.172) \mathrm{WGI}-3.642(-1.8333) \mathrm{CPI}-1.463(-0.308) \mathrm{GCI}-4.436$

$(-0.973)$ OECD

\footnotetext{
${ }^{3}$ In this study, we selected 74 aquaculture countries, including top aquaculture producers, small producers, and aquaculture producers where the aquaculture industry is still in its infancy. Therefore, in addition to main econometric work, the research question was tested using the data for the top 30 aquaculture producers based on the average aquaculture quantity in 2012 and 2013. Detailed results can be provided by the corresponding author on request.
} 


\section{DISCUSSION AND CONCLUSION}

At the outset, the main hypothesis was that high-quality institutions would have positive effects on aquaculture production. This hypothesis was partly based on the latest findings in the resource curse literature, in particular that high-quality institutions increase the economic benefits to a country through natural resource industries $[12,13]$, and partly based on the suggestion often cited in the aquaculture literature that good governance measures have to be implemented by aquaculture countries with a view to the future [16,32]. The statistical results for 74 countries do not support these expectations. The econometric analysis suggest that the aquaculture growth rate has a weak, though hardly statistically significant, negative correlation with the quality of institutions. There is a similar result that stringent environmental regulations are negatively related to aquaculture growth [33]. Panel-data regression results indicated that the annual growth rates in aquaculture production are not significantly influenced by the quality of institutions (WGI and CPI). While, the sign of the coefficient for GCI is negative, it is weakly significant (at a 10\% level). As overall, empirical results suggest that the quality of national institutions did not have significant effect on aquaculture growth.

If so, why have aquaculture countries been demanded to follow high quality institutions (policies, rules, laws, regulatory measures) by international organizations in recent decades? To answer this, consideration was given to the important turning points in the global aquaculture sector. First, this is the average picture. However, as noted above, the results among the aquaculture nations are mixed. Second, aquaculture has been a part of the agricultural sector since ancient times [4], it has become more popular as an animal foodproducing sector over the last few decades, and has expanded since wild capture started to stabilize. The global aquaculture sector has been described as going through several notable phases, categorized based on changes identified in the patterns of production and farming methods [34]. Remarkable changes occurred in the aquaculture sector from the 1990s onwards, 
when it was recognized worldwide that the practice of aquaculture might degrade the environment and threaten biodiversity and the sustainability of the sector itself. A number of disease incidents were recorded in many aquaculture countries, e.g. Chile. To reduce the negative impacts caused by aquaculture and to sustain production, several new policies, rules and regulatory measures were formulated by international organizations (governmental and nongovernmental), based on measures deemed necessary at the time to guide aquaculture countries. Even though, how well aquaculture standards address environmental and ethical issues is still debatable. A study carried out as a part of Sustaining Ethical Aquaculture Trade project indicates that there are weaknesses in the current ethical framework of standards related to aquaculture [35]. Regulatory measures most often used are command and control instruments like feed quotas, water use limits and aquaculture moratoriums to control effluents, especially of nitrogen. These restrictions might limit aquaculture production in some countries where there are inadequate technologies, skilled manpower and financial support for carrying out farming based on the recommended methods. This could be the reason why there is a weak negative correlation between the aquaculture growth rates and the quality of institutions.

On the other hand, institutions may have an indirect positive influence on the development of the aquaculture sector. Proper licensing reduces the negative impacts caused by aquaculture. Extension services, training programs, provision of fingerlings and vaccines improve farming. Microcredit schemes, insurance and incentives support aquaculture farmers when production is limited by climatic constraints. Improving infrastructure facilities in a country (electricity, irrigation and roads) facilitates aquaculture production. Technology and skills transfer increase aquaculture productivity. Trade policies help to reduce price fluctuations and market failures and increase aquaculture value.

Aquaculture production in some industrialized countries (the United States of America, Spain, France, Italy, Japan and the Republic of Korea) has fallen in recent years. The reason noted in 
the FAO report is that these countries import seafood from other countries where the cost of production is lower [2]. This trading strategy has indirectly caused a reduction in the quantity of aquaculture. In a sense, these industrialized countries could enjoy many benefits through this trading strategy, satisfying their seafood requirements and reducing the environmental damage caused by aquaculture, and thus managing marine resources from a long-term perspective. Implementation of strict environmental regulation has also been suggested as one of the reasons for the reduction in aquaculture production in the United States of America and European countries [36-38].

The trend in aquaculture production over time shows that total aquaculture production from the Asian and African regions has been increasing continuously compared to that in other regions, i.e. the Americas, Europe and Oceania. Expansion of farming areas and technology transfer could be reasons for the continuous increase in aquaculture quantity in the Asian and African regions. Countries that show a more or less stable production trend might have reached their maximum expansion capacity in aquaculture. The Asian and African regions predominantly include less-developed or developing countries, where aquaculture farming is practiced as a source of livelihood to overcome problems including poverty, malnutrition and unemployment, and to derive foreign exchange earnings. This rapid expansion has been most pronounced in countries with abundant marine resources, including mangrove forests, inland water reservoirs, and extensive coastal margins [8]. There have been depredations as a result: Huge areas of mangrove forest have been destroyed for shrimp farming, wild capture have been used as feed, lagoons and rivers have been exploited as water sources for intensive farming, and coastal margins have been occupied for mariculture [20].

As noted above, aquaculture production depends on several factors and the interaction between these factors. Most inputs, except labor, are traded internationally, whereas institutions are mainly national. In this study, only the institutions were considered, omitting other factors from 
the econometric analysis, mainly due to lack of data. Therefore the simple claim that different growth rates among the countries are solely due to the variation in the quality of institutions, cannot be verified. The variation in the annual aquaculture growth rate among countries could be due to differences in factors such as marine resource abundance, climate, species diversity (finfish, crustaceans, molluscs and aquatic plants), farming techniques, and markets that are important for production.

Marine resources abundance provide opportunities to use various farming environments (freshwater, brackish water and mariculture) and to adapt diversified farming systems (ponds, pens/cage, paddy fields, culture based fisheries, integrated farming). Intensified farming and improved nutrition contributes to increased yield per area unit [7]. Aquatic species are selected based on climate factors in the region, especially precipitation and temperature. Extreme weather events and natural disasters that occurred in recent years caused significant impact on aquaculture production. For example, in 2011, the aquaculture sectors in Thailand and Japan suffered due to catastrophic natural disasters [39].

Seafood is an important source of animal protein. It is projected that fish supply from the global aquaculture sector will continue to increase up to 93.6 million tons in 2030 based on observed regional trends in seafood production and consumption, and using a global, partial-equilibrium, multi-market model. Aquaculture expansion is expected in Asian and African regions during 2010 - 2030 [6]. Current statistics on fish production and the predicted fish production from the global aquaculture indicate continued significance of aquaculture in global seafood supply.

In this context, the aquaculture sector is a special case compared to other natural resource industries, this is termed the "aquaculture paradox." Effective institutions limit the quantity of aquaculture production, but they may help to reduce the negative impacts caused by this industry. The role of institution on growth of natural resources industries and overall economic 
growth varies with type of natural resource used as inputs- recall the resource curse discussion above. It could have been expected that the aquaculture performance of countries would change over time, depending on opportunities and constraints. Growing seafood demand creates new market opportunities for aquaculture producers. Primary food producing sectors, including aquaculture, are highly related to climate factors and likely to be affected by climate change [40]. A policy implication of the "aquaculture paradox" is for countries to consider all input factors, including institutions, although the quality of national institutions on the average does not seem to matter much, statistically speaking. Having effective institutions in aquaculture production would help to internalized negative externalities caused by aquaculture, conserve marine resources, and sustain the contribution to global seafood production in the long term.

One suggestion for future study is that it would be better to estimate the econometric model by including many explanatory variables (input and price factors, including fuel oil) that may influence production, if and when such data becomes internationally available.

\section{ACKNOWLEDGEMENTS}

We would like to thank Øystein Myrland, UiT The Arctic University of Norway, for helping with the data analysis using the $\mathrm{R}$ package, and an anonymous reviewer for comments and suggestions on a previous draft. This research did not receive any specific grant from funding agencies in the public, commercial, or not-for-profit sectors. PhD scholarship from UiT is acknowledged.

\section{REFERENCES}

[1] FAO- Food and Agriculture Organization of the United Nations. The state of world fisheries and aquaculture 2016, Rome, 2016.

[2] FAO- Food and Agriculture Organization of the United Nations. The state of world fisheries and aquaculture 2014, Rome, 2014. 
[3] J.L. Anderson, Aquaculture and the future, Marine Resource Economics 17(2) (2002) $133-152$.

[4] F. Asche, Farming the sea, Marine Resource Economics 23(4) (2008) 527-547.

[5] C.L. Delgado, N. Wada, M.W. Rosengrant, S. Meijer, M. Ahmed, Fish 2020: Supply and demand in changing global market. Washington, DC: IFPRI, 2003.

[6] M. Kobayashi, S. Msangi, M. Batka, S. Vannuccini, M.M. Dey, J.L. Anderson, Fish to 2030: The role and opportunity for aquaculture, Aquaculture Economics \& Management 19(3) (2015) 282-300.

[7] G. Kumar, C.R. Engle, Technological advances that led to growth of shrimp, salmon and tilapia farming, Reviews in Fisheries Science \& Aquaculture 24(2) (2016) 136-152.

[8] J. Bostock, B. McAndrew, R. Richards, K. Jauncey, T. Telfer, K. Lorenzen, ..., R. Corner, Aquaculture: Global status and trends, Philosophical Transactions of the Royal Society B 365(2010) 2897-2912.

[9] J.F. Muir, J.A. Young, Aquaculture and marine fisheries: will capture fisheries remain competitive?, Journal of Northwest Atlantic Fishery Science 23(1998) 157-174.

[10] B. Aarset, S. Jakobsen, Political regulation and radical institutional change: The case of aquaculture in Norway, Marine Policy 33 (2009) 280-287.

[11] R.E. Hall, C.I. Jones, Why do some countries produce so much more output per worker than others?, The Quarterly Journal of Economics 114(1) (1999) 83-116.

[12] H. Mehlum, K. Moene, R. Torvik, Institutions and the resource curse, Economic Journal 116 (2006) 1-20. 
[13] A.D. Boschini, J. Pettersson, J. Roine, Resource curse or not: A question of appropriability, Scandinavian Journal of Economics 109(3) (2007) 593-617.

[14] F.V.D. Ploeg, Natural resources: Curse or blessing?, Journal of Economic Literature 49(2) (2011) 366-420.

[15] J. S. Sachs, A.M. Warner, The curse of natural resources, European Economic Review 45 (2001) 827-838.

[16] M. D. Smith, C. A. Roheim, L. B. Crowder, B.S. Halpern, M. Turnipseed, J. L. Anderson,... K.A. Selkoe, Sustainability and global seafood, Science 327(2010) 784 - 786.

[17] S. Tveterås, F. Asche, M.F. Bellemare, M.D. Smith, A.G. Guttormsen, A. Lem,..., S. Vannuccini, Fish is food - The FAO's fish price index, PLoS ONE 7(5) (2012) 1-10.

[18] F. Asche, M.F. Bellemare, C. Roheim, M.D. Smith, S. Tveterås, Fair enough? Food security and the international trade of seafood, World Developemnt 67(2015) 151-160.

[19] O. Flaaten, Institutional quality and catch performance of fishing nations, Marine Policy 38(2013) 267-276.

[20] R.L. Naylor, R.J. Goldburg, J.H. Primavera, N. Kautsky, M.C.M. Beveridge, J. Clay, ... M.Troell, Effect of aquaculture on worldfisher supplies, Nature 405(2000) 1017-1024.

[21] O. Torrissen, S. Jones, F. Asche, A. Guttormsen, O.T. Skilbrei, F. Nilsen, ..., D. Jackson, Salmon lice - impact on wild salmonids and salmon aquaculture, Journal of Fish Diseases 36(2013) 171-194.

[22] Y. Hayami, V.W. Ruttan, Agricultural productivity differences among countries, The American Economic Review 60(5) (1970) 895-911. 
[23] M. Lio, M.C. Liu, Governance and agriculture productivity: A cross-national analysis, Food Policy 33(2008) 504-512.

[24] FAO- Food and Agriculture Organization of the United Nations. Rome: FishstatJ universal software for fishery statistical time series. Total fishery, capture and aquaculture production 1950-2013. http://www.fao.org/fishery/statistics/software/fishstatj/en

[25] World Bank: The World governance Indicator.

http://info.worldbank.org/governance/wgi/index.aspx\#home

[26] Transparency International: Corruption Perception Index, http://www.transparency.org/research/cpi/

[27] K. Schwab, The global competitiveness report 2010 - 2011. World Economic Forum. Geneva, Switzerland, 2010.

[28] World Economic Forum: Global Competitiveness Report: http://www3.weforum.org/docs/WEF_GlobalCompetitivenessReport_2013-14.pdf

[29] C. Kleiber, A. Zeileis, Applied econometrics with R, Springer Science + Business Media. New York, USA, 2008.

[30] Y. Honda, Testing the error components model with non-normal disturbances, Review of Economic Studies 52(1985) 681-690.

[31] J.A. Hausman, W.E.Taylor, Panel data and unobservable individual effects, Econometrica 49(1981) 1377-1398.

[32] N. Hishamunda, N.B. Ridler, Policies at the farm level to promote commercial aquaculture in sub-Saharan Africa, Aquaculture Economics\& Management 8(1-2) (2004) 85-98. 
[33] T.G. Abate, R. Nielsen, R. Tveterås, Stringency of environmental regulation and aquaculture growth: A cross country analysis, Aquaculture Economics \& Management 20(2) (2016) 201-221.

[34] S.S. De Silva, F.B. Davy, Aquaculture successes in Asia: Contributing to sustained development and poverty alleviation, in: S.S De Silva, F.B Davy (Eds.), Success stories in Asian aquaculture, Springer Science + Business Media, Dordrecht, Heidelberg, London, New York, 2010, pp. 1-14.

[35] A.S. Haugen, S. Bremer, M. Kaiser, Weakness in the ethical framework of aquaculture related standards, Marine Policy 75(2017) 11-18.

[36] C.R. Engle, N.M. Stone, Competitiveness of U.S. aquaculture within the current U.S. regulatory framework, Aquaculture Economics \& Management 17(3) (2013) 251-280.

[37] G. Knapp, M.C. Rubino, The political economics of marine aquaculture in the United States, Reviews in Fisheries Science \& Aquaculture 24(3) (2016) 213-229.

[38] R. Nielsen, F. Asche, M.Nielsen, Restructuring European freshwater aquaculture from family-oriented to large-scale firms - lessons from Danish aquaculture, Aquaculture Research 47(2016) 3852-3866.

[39] FAO- Food and Agriculture Organization of the United Nations, Fisheries and aquaculture department, Global aquaculture production statistic for the year, 2011 ftp://ftp.fao.org/fi/news/GlobalAquacultureProductionStatistics2011.pdf

[40] J.R. Porter, L. Xie, A.J. Cochrane, S.M. Howden, M.M. Iqbal, D.B. Lobell, M.I. Travasso, Food security and food production systems, in C.B. Field, V. R. Barrors, D.J. Dokken, K.J. Mach, M.D. Mastrandrea, T.E. Bilir...L.L.White (Eds), Climate change: Impacts, Adaption, and Vulnerability. Part A: Global and sectoral aspects. Contribution of working Group II to fifth assessment report of the Intergovernmental Panel on Climate Change, Cambridge University press, Cambridge, United Kingdom and New York, NY, USA, 2014, pp 485-533. 


\section{TABLES}

\section{TABLE 1}

Panel data regression results

\begin{tabular}{|c|c|c|c|c|}
\hline & $\begin{array}{l}\text { Regression5 } \\
i^{\text {qty }}\end{array}$ & $\begin{array}{l}\text { Regression } 6 \\
i^{\text {val }}\end{array}$ & $\begin{array}{l}\text { Regression } 7 \\
i^{\text {qty }}\end{array}$ & $\begin{array}{l}\text { Regression } 8 \\
i^{\text {val }}\end{array}$ \\
\hline Intercept & $\begin{array}{l}26.951 * * \\
(2.544)\end{array}$ & $\begin{array}{l}31.400 * * * \\
(2.658)\end{array}$ & $\begin{array}{l}24.900 * * \\
(2.239)\end{array}$ & $\begin{array}{l}25.150 * \\
(1.960)\end{array}$ \\
\hline WGI & $\begin{array}{l}-0.174 \\
(-0.067)\end{array}$ & $\begin{array}{l}2.813 \\
(0.997)\end{array}$ & $\begin{array}{l}-0.105 \\
(-0.042)\end{array}$ & $\begin{array}{l}2.070 \\
(0.737)\end{array}$ \\
\hline CPI & $\begin{array}{l}0.328 \\
(0.332)\end{array}$ & $\begin{array}{l}-0.239 \\
(-0.227)\end{array}$ & $\begin{array}{l}0.133 \\
(0.137)\end{array}$ & $\begin{array}{l}-0.590 \\
(-0.544)\end{array}$ \\
\hline GCI & $\begin{array}{l}-4.890 * \\
(-1.86)\end{array}$ & $\begin{array}{l}-4.802 \\
(-1.633)\end{array}$ & $\begin{array}{l}-4.324 \\
(-1.587)\end{array}$ & $\begin{array}{l}-3.258 \\
(-1.032)\end{array}$ \\
\hline OECD & $\begin{array}{l}-3.181 \\
(-1.251)\end{array}$ & $\begin{array}{l}-4.281 \\
(-1.615)\end{array}$ & & \\
\hline R1 (Africa) & & & $\begin{array}{l}7.350 * * \\
(2.444)\end{array}$ & $\begin{array}{l}9.285 * * * \\
(2.860)\end{array}$ \\
\hline R2 (America) & & & $\begin{array}{l}-0.669 \\
(-0.296)\end{array}$ & $\begin{array}{l}-0.606 \\
(-0.248)\end{array}$ \\
\hline R4 (Europe) & & & $\begin{array}{l}-3.786 * \\
(-1.661)\end{array}$ & $\begin{array}{l}-2.775 \\
(-1.124)\end{array}$ \\
\hline R5 (Oceania) & & & $\begin{array}{l}0.204 \\
(0.036)\end{array}$ & $\begin{array}{c}1.348 \\
(0.222)\end{array}$ \\
\hline
\end{tabular}

Notes: The numbers in parentheses are $t$-values; $i^{\text {aty }}, i^{\text {val }}$ are annual changes in quantity and value, respectively (dependent variable). $*$, **, and $* * *$ denote significance at the $10 \%, 5 \%$, and $1 \%$ levels, respectively. 


\section{FIGURES}

30

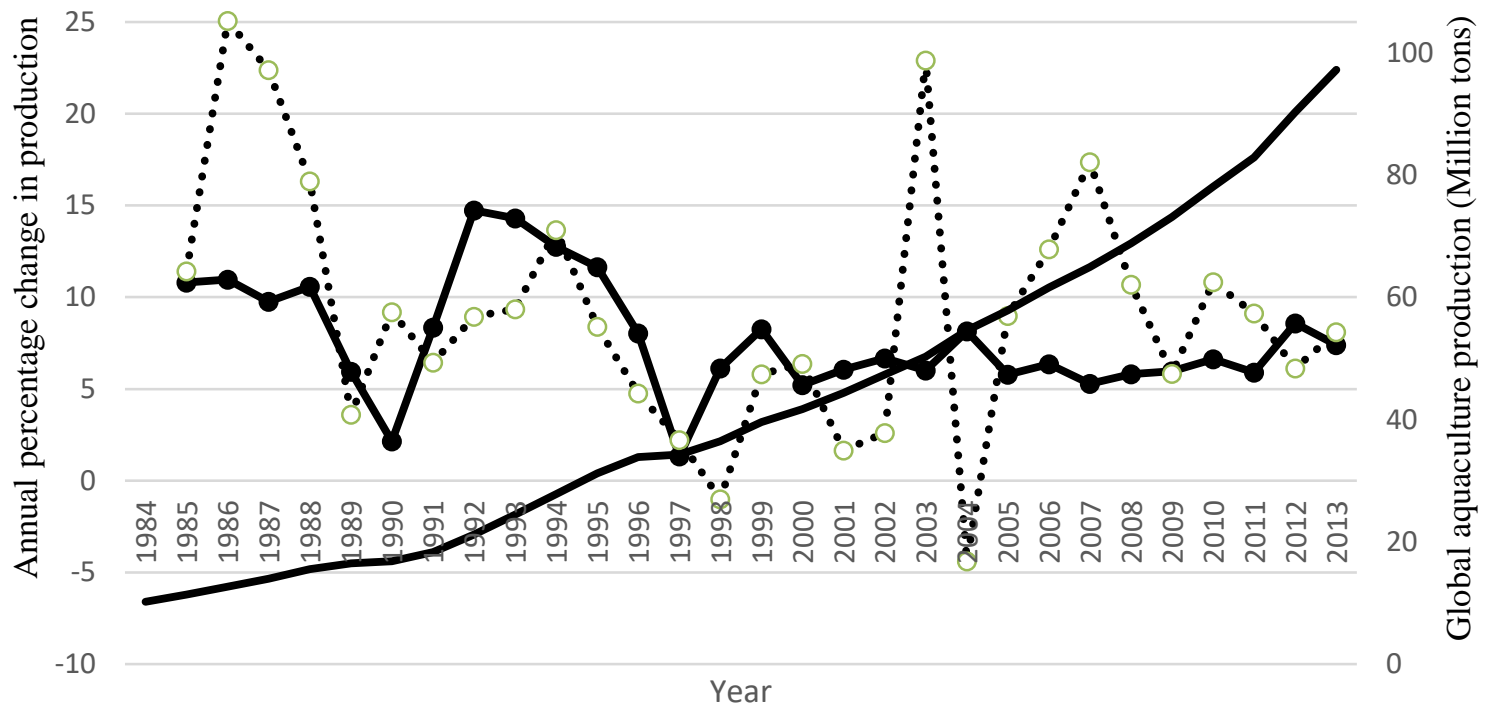

$\longrightarrow$ i_Quantity $\quad \cdots \cdot \cdot$ i_Value $\longrightarrow$ Production (Million tons)

Fig. 1. Average annual change in total global aquaculture production (1984-2013). Source: FishStat, FAO, 2015. 


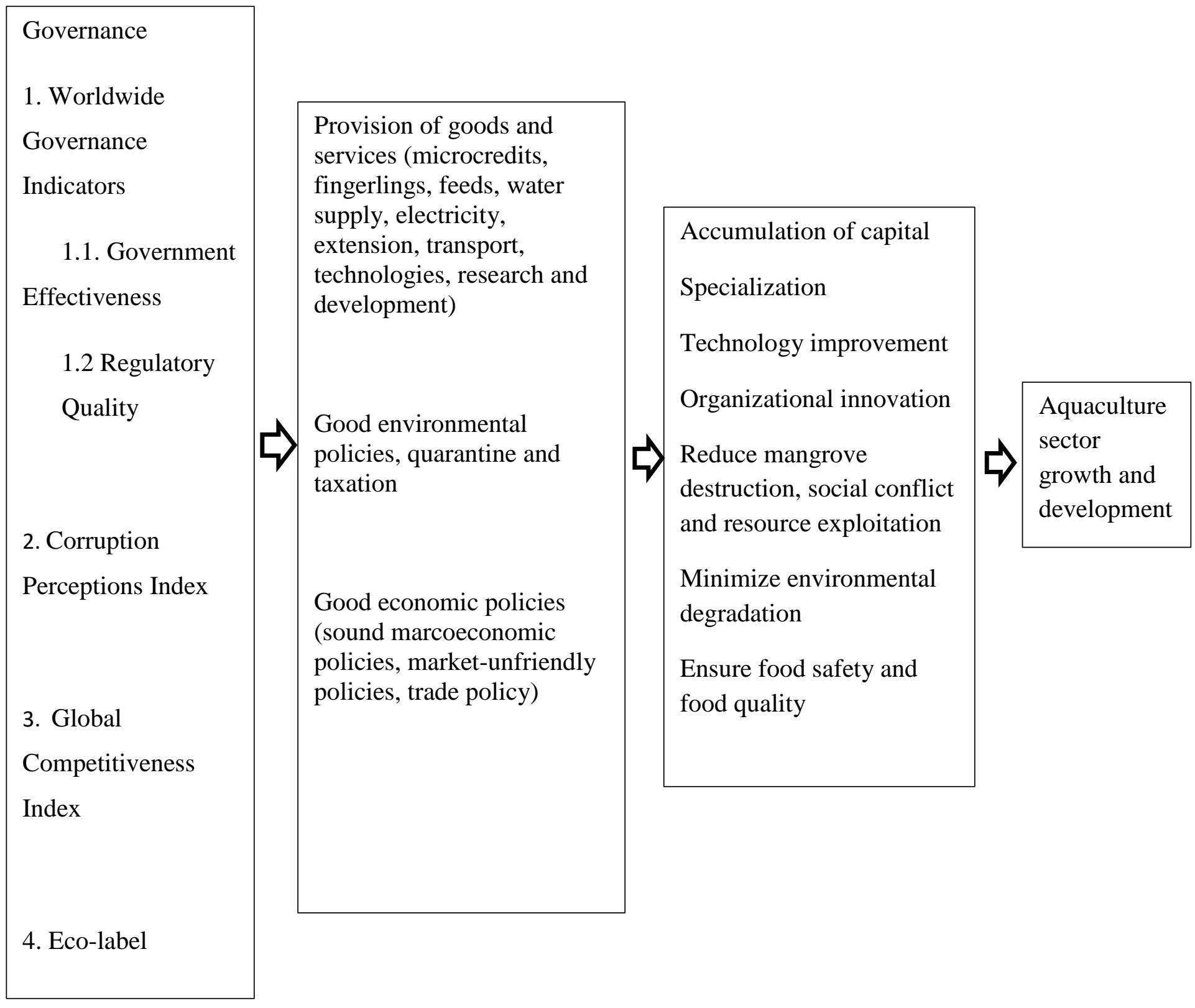

Fig. 2. Governance and aquaculture growth elements. 


\section{Appendix}

TABLE A1

Average annual change in aquaculture production in the period 1985-2013 for the 74 countries and the quality of institution in those countries

\begin{tabular}{|c|c|c|c|c|c|c|c|c|}
\hline & \multirow[t]{2}{*}{ Name } & \multicolumn{2}{|c|}{ Production } & \multicolumn{2}{|c|}{$\begin{array}{l}\text { Average annual } \\
\text { change }(\%)\end{array}$} & \multicolumn{3}{|c|}{ Indices } \\
\hline & & Quantity & Value & $i^{\mathrm{qty}}$ & $i^{\mathrm{val}}$ & WGI & CPI & GCI \\
\hline 1 & China & 55528.05 & 71082.38 & 9.22 & 10.86 & -0.15 & 3.95 & 4.84 \\
\hline 2 & India & 4384.04 & 9802.33 & 7.09 & 10.49 & -0.33 & 3.60 & 4.30 \\
\hline 3 & Indonesia & 11373.53 & 9305.99 & 12.48 & 11.96 & -0.25 & 3.20 & 4.47 \\
\hline 4 & Chile & 1060.63 & 6777.76 & 17.43 & 23.64 & 1.38 & 7.15 & 4.63 \\
\hline 5 & Vietnam & 3307.29 & 6129.33 & 11.72 & 12.58 & -0.48 & 3.10 & 4.15 \\
\hline 6 & Norway & 1284.49 & 6031.87 & 13.41 & 13.09 & 1.74 & 8.55 & 5.30 \\
\hline 7 & Japan & 1050.50 & 5164.12 & -0.46 & 2.56 & 1.30 & 7.40 & 5.40 \\
\hline 8 & Bangladesh & 1792.94 & 4162.74 & 9.65 & 11.83 & -0.88 & 2.65 & 3.68 \\
\hline 9 & Thailand & 1164.52 & 3324.84 & 8.00 & 12.12 & 0.22 & 3.60 & 4.53 \\
\hline 10 & Philippines & 2457.68 & 2198.43 & 5.78 & 5.50 & 0.00 & 3.50 & 4.26 \\
\hline 11 & Egypt & 1057.64 & 2049.84 & 12.23 & 16.65 & -0.71 & 3.20 & 3.68 \\
\hline 12 & Korea, Republic of & 1521.34 & 1835.75 & 2.60 & 6.98 & 1.05 & 5.55 & 5.07 \\
\hline 13 & Ecuador & 327.32 & 1638.25 & 8.24 & 7.09 & -0.74 & 3.35 & 4.06 \\
\hline 14 & Myanmar & 909.57 & 1607.76 & 18.96 & 18.00 & -1.60 & 1.80 & 3.23 \\
\hline 15 & Brazil & 477.52 & 1380.63 & 13.54 & 12.67 & -0.01 & 4.25 & 4.37 \\
\hline 16 & Taiwan & 347.79 & 1282.49 & 1.21 & 2.60 & 1.16 & 6.10 & 5.29 \\
\hline 17 & $\begin{array}{l}\text { United States of } \\
\text { America }\end{array}$ & 430.54 & 1108.42 & 1.00 & 3.17 & 1.39 & 7.30 & 5.48 \\
\hline 18 & United Kingdom & 198.83 & 1034.85 & 8.41 & 9.48 & 1.60 & 7.50 & 5.41 \\
\hline 19 & Iran & 310.95 & 911.59 & 10.16 & 10.71 & -1.04 & 2.65 & 4.15 \\
\hline 20 & Turkey & 223.33 & 903.27 & 16.10 & 17.51 & 0.40 & 4.95 & 4.45 \\
\hline 21 & France & 203.71 & 886.44 & -0.10 & 4.64 & 1.26 & 7.10 & 5.08 \\
\hline 22 & Canada & 172.67 & 880.79 & 10.86 & 15.54 & 1.73 & 8.25 & 5.24 \\
\hline 23 & Australia & 76.65 & 856.74 & 7.59 & 12.81 & 1.70 & 8.30 & 5.11 \\
\hline 24 & Greece & 141.09 & 815.37 & 14.46 & 17.04 & 0.47 & 3.80 & 3.90 \\
\hline 25 & Malaysia & 582.79 & 809.15 & 8.13 & 12.35 & 0.82 & 4.95 & 5.05 \\
\hline 26 & Nigeria & 266.30 & 755.52 & 12.89 & 16.51 & -0.86 & 2.60 & 3.62 \\
\hline 27 & Peru & 98.99 & 675.61 & 10.33 & 11.65 & 0.16 & 3.80 & 4.27 \\
\hline 28 & Mexico & 156.27 & 670.60 & 9.53 & 15.03 & 0.39 & 3.40 & 4.35 \\
\hline 29 & Russian Federation & 151.00 & 519.65 & 0.10 & 4.13 & -0.38 & 2.80 & 4.23 \\
\hline 30 & Italy & 162.62 & 514.44 & 1.72 & 3.94 & 0.59 & 4.25 & 4.44 \\
\hline 31 & Spain & 243.94 & 502.19 & -0.19 & 2.91 & 1.03 & 6.20 & 4.59 \\
\hline 32 & New Zealand & 98.64 & 382.13 & 7.71 & 15.35 & 1.80 & 9.05 & 5.10 \\
\hline 33 & Honduras & 61.43 & 319.11 & 17.02 & 17.89 & -0.46 & 2.70 & 3.79 \\
\hline 34 & Colombia & 89.53 & 283.62 & 16.64 & 15.30 & 0.21 & 3.60 & 4.19 \\
\hline 35 & Saudi Arabia & 23.17 & 234.08 & 21.61 & 25.32 & 0.07 & 4.50 & 5.15 \\
\hline
\end{tabular}




\begin{tabular}{|c|c|c|c|c|c|c|c|c|}
\hline 36 & Pakistan & 145.48 & 219.46 & 10.14 & 10.41 & -0.76 & 2.75 & 3.47 \\
\hline 37 & Uganda & 96.98 & 213.56 & 28.63 & 35.98 & -0.41 & 2.75 & 3.49 \\
\hline 38 & Ireland & 35.15 & 157.97 & 3.38 & 9.90 & 1.53 & 7.05 & 4.92 \\
\hline 39 & Lao & 104.95 & 157.42 & 12.41 & 13.86 & -0.83 & 2.35 & 4.08 \\
\hline 40 & Netherlands & 53.28 & 145.75 & -1.81 & 3.29 & 1.77 & 8.35 & 5.46 \\
\hline 41 & Cambodia & 82.00 & 143.89 & 12.76 & 13.00 & -0.61 & 2.10 & 4.01 \\
\hline 42 & Denmark & 55.10 & 133.51 & 2.98 & 3.15 & 1.88 & 9.05 & 5.24 \\
\hline 43 & $\begin{array}{l}\text { Korea, Democratic } \\
\text { People's Republic }\end{array}$ & 508.35 & 116.22 & -1.24 & -3.45 & -2.22 & 0.80 & $2.42^{\mathrm{a}}$ \\
\hline 44 & Iraq & 19.55 & 100.29 & 5.28 & 7.85 & -1.18 & 1.70 & $2.55^{\mathrm{a}}$ \\
\hline 45 & Poland & 33.73 & 100.07 & 1.86 & 3.11 & 0.85 & 5.90 & 4.46 \\
\hline 46 & $\begin{array}{l}\text { Venezuela, } \\
\text { Bolivarian Republic }\end{array}$ & 26.35 & 99.26 & 12.33 & 15.14 & -1.36 & 1.95 & 3.41 \\
\hline 47 & Germany & 25.82 & 98.78 & -4.01 & -1.10 & 1.54 & 7.85 & 5.50 \\
\hline 48 & Israel & 21.24 & 96.45 & 1.97 & 5.62 & 1.20 & 6.05 & 4.98 \\
\hline 49 & Guatemala & 17.40 & 86.01 & 15.01 & 14.19 & -0.47 & 3.10 & 4.03 \\
\hline 50 & Nepal & 35.26 & 83.30 & 9.27 & 12.14 & -0.90 & 2.90 & 3.58 \\
\hline 51 & Costa Rica & 28.68 & 82.27 & 18.87 & 19.61 & 0.52 & 5.35 & 4.35 \\
\hline 52 & Tunisia & 10.38 & 70.82 & 15.60 & 22.82 & -0.14 & 4.10 & 4.06 \\
\hline 53 & Croatia & 11.23 & 68.53 & 1.84 & 4.89 & 0.56 & 4.70 & 4.09 \\
\hline 54 & Portugal & 9.10 & 67.20 & 1.30 & 3.04 & 0.97 & 6.25 & 4.40 \\
\hline 55 & Ukraine & 23.45 & 65.32 & -4.62 & -1.49 & -0.62 & 2.55 & 4.10 \\
\hline 56 & Ghana & 29.98 & 63.99 & 15.39 & 18.09 & 0.01 & 4.55 & 3.74 \\
\hline 57 & Sweden & 13.56 & 61.39 & 5.19 & 7.75 & 1.90 & 8.85 & 5.51 \\
\hline 58 & South Africa & 6.00 & 57.42 & 8.95 & 11.25 & 0.39 & 4.25 & 4.37 \\
\hline 59 & Finland & 13.14 & 57.00 & 1.02 & 0.85 & 2.01 & 8.95 & 5.55 \\
\hline 60 & Nicaragua & 25.38 & 55.78 & 25.18 & 21.40 & -0.58 & 2.85 & 3.79 \\
\hline 61 & Czech Republic & 20.06 & 51.66 & 0.16 & 0.03 & 0.99 & 4.85 & 4.47 \\
\hline 62 & Madagascar & 10.87 & 46.97 & 13.66 & 16.58 & -0.86 & 3.00 & 3.40 \\
\hline 63 & Iceland & 7.24 & 43.76 & 14.64 & 14.74 & 1.28 & 8.00 & 4.70 \\
\hline 64 & Sri Lanka & 19.86 & 43.45 & 17.22 & 14.91 & -0.19 & 3.85 & 4.21 \\
\hline 65 & Belarus & 14.52 & 42.89 & -0.16 & 3.06 & -1.02 & 3.00 & $2.83^{\mathrm{a}}$ \\
\hline 66 & Panama & 7.90 & 37.29 & 4.64 & 3.05 & 0.35 & 3.65 & 4.50 \\
\hline 67 & Hungary & 15.03 & 37.01 & -0.52 & 3.56 & 0.78 & 5.45 & 4.28 \\
\hline 68 & Cuba & 27.88 & 36.78 & 6.51 & 7.79 & -1.02 & 4.70 & $3.57^{\mathrm{a}}$ \\
\hline 69 & Bulgaria & 9.06 & 27.13 & -1.17 & 1.01 & 0.34 & 4.10 & 4.29 \\
\hline 70 & Romania & 10.51 & 26.81 & -5.10 & -5.03 & 0.18 & 4.35 & 4.10 \\
\hline 71 & Austria & 3.18 & 23.76 & -0.86 & 2.98 & 1.53 & 6.90 & 5.19 \\
\hline 72 & Singapore & 4.40 & 20.77 & 4.68 & 6.88 & 2.04 & 8.65 & 5.64 \\
\hline 73 & China, Hong Kong & 3.93 & 20.54 & -2.60 & -0.23 & 1.86 & 7.60 & 5.44 \\
\hline \multirow[t]{3}{*}{74} & Syria & 5.10 & 16.76 & 2.64 & 4.94 & -1.43 & 2.15 & $2.5^{\mathrm{a}}$ \\
\hline & Total 74 countries & 93328.39 & 149915.33 & & & & & \\
\hline & Global total & 93741.08 & 151141.79 & & & & & \\
\hline
\end{tabular}

Notes: Aquaculture quantity (in thousands tons) and value (million US\$), scores for indices are the average for 2012-2013, ${ }^{a}$ inserted by interpolation, using other indices (WGI and CPI). 


\section{TABLE A2}

Correlation between the main variables

\begin{tabular}{llllllll}
\hline & $i^{\text {qty }}$ & $i^{\text {val }}$ & WGI & CPI & GCI & OECD & BAP_ASC \\
\hline WGI & -0.327 & -0.232 & 1.000 & & & & \\
CPI & -0.316 & -0.227 & 0.9444 & 1.000 & & & \\
GCI & -0.268 & -0.203 & 0.902 & 0.850 & 1.000 & & \\
OECD & -0.316 & -0.217 & 0.737 & 0.733 & 0.582 & 1.000 & \\
BAP_ASC & -0.118 & -0.124 & 0.340 & 0.340 & 0.457 & 0.310 & 1.000
\end{tabular}

Notes: $i^{\text {qty }}, i^{\text {val }}$ are the average annual percentage change in aquaculture quantity and value, respectively. 


\section{TABLE A3}

Cross-country regression results

\begin{tabular}{|c|c|c|c|c|}
\hline & $\begin{array}{l}\text { Regression } 1 \\
i^{\text {qty }}\end{array}$ & $\begin{array}{l}\text { Regression } 2 \\
i^{\mathrm{val}}\end{array}$ & $\begin{array}{l}\text { Regression } 3 \\
i^{\text {qty }}\end{array}$ & $\begin{array}{l}\text { Regression } 4 \\
i^{\mathrm{val}}\end{array}$ \\
\hline Intercept & $\begin{array}{l}5.514 \\
(0.423)\end{array}$ & $\begin{array}{l}9.994 \\
(0.731)\end{array}$ & $\begin{array}{l}8.023 \\
(0.678)\end{array}$ & $\begin{array}{l}12.685 \\
(1.066)\end{array}$ \\
\hline WGI & $\begin{array}{l}-2.045 \\
(-0.634)\end{array}$ & $\begin{array}{l}-1.111 \\
(-0.329)\end{array}$ & $\begin{array}{l}-0.517 \\
(-0.190)\end{array}$ & $\begin{array}{l}0.914 \\
(0.333)\end{array}$ \\
\hline CPI & $\begin{array}{l}-0.003 \\
(-0.025)\end{array}$ & $\begin{array}{l}-0.010 \\
(-0.083)\end{array}$ & $\begin{array}{l}-0.018 \\
(-0.180)\end{array}$ & $\begin{array}{l}-0.041 \\
(-0.410)\end{array}$ \\
\hline GCI & $\begin{array}{l}0.901 \\
(0.309)\end{array}$ & $\begin{array}{l}0.355 \\
(0.116)\end{array}$ & $\begin{array}{l}0.210 \\
(0.081)\end{array}$ & $\begin{array}{l}-0.242 \\
(-0.093)\end{array}$ \\
\hline OECD & $\begin{array}{l}-2.173 \\
(-0.791)\end{array}$ & $\begin{array}{l}-1.301 \\
(-0.452)\end{array}$ & & \\
\hline BAP_ASC & $\begin{array}{l}-0.203 \\
(-0.101)\end{array}$ & $\begin{array}{l}-0.767 \\
(-0.364)\end{array}$ & $\begin{array}{l}0.023 \\
(0.013)\end{array}$ & $\begin{array}{l}-0.013 \\
(-0.008)\end{array}$ \\
\hline R1 (Africa) & & & $\begin{array}{l}6.971 * * \\
(2.562)\end{array}$ & $\begin{array}{l}9.731 * * * \\
(3.555)\end{array}$ \\
\hline R2 (America) & & & $\begin{array}{l}4.394 * * \\
(2.163)\end{array}$ & $\begin{array}{l}3.641 * \\
(1.781)\end{array}$ \\
\hline R4 (Europe) & & & $\begin{array}{l}-5.241 * * \\
(-2.471)\end{array}$ & $\begin{array}{l}-5.311 * * \\
(-2.489)\end{array}$ \\
\hline R5 (Oceania) & & & $\begin{array}{l}1.037 \\
(0.207)\end{array}$ & $\begin{array}{l}4.688 \\
(0.929)\end{array}$ \\
\hline
\end{tabular}

Notes: The numbers in parentheses are $t$-values; $i^{\mathrm{qty}}, i^{\mathrm{val}}$ are average annual changes in quantity and value, respectively (dependent variable). *, **, and *** denote significance at the $10 \%$, $5 \%$, and $1 \%$ levels respectively. 